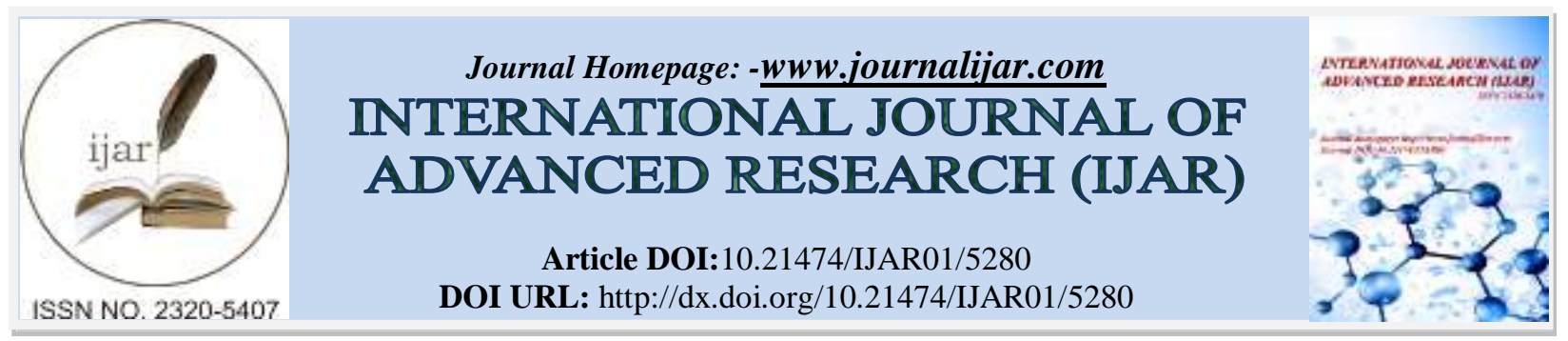

RESEARCH ARTICLE

\title{
RECONSTRUCTION OF REGULATION OF AUTHORITY OF EXECUTION OF DECISION OF NATIONAL SYARI'AH ARBITRATION SYSTEM IN DECISION OF ECONOMY SHARI'A DISPUTE IN INDONESIA BASED ON JUSTICE VALUE.
}

Tamah, Gunarto, Akhmad Khisni and Anis Mashdurohatun.

Faculty Of Law Universitas Sultan Agung Semarang Indonesia.

\section{Manuscript Info}

Manuscript History

Received: 25 June 2017

Final Accepted: 27 July 2017

Published: August 2017

Keywords:-

Reconstruction, Arbitrary Execution

Authority, Shari'a Economy, Justice Value.

\begin{abstract}
This study aims to examine and analyze the authority of the National Sharia Arbitration Board in the Sharia Economic Dispute in Indonesia and to find the reconstruction of the authority of the execution of the decision of the National Syari'ah Arbitration Board in the sharia economic dispute in Indonesia. The approach method used in this research is normative juridical, using secondary data type (sourced from primary legal Material, secondary law material and tertiary legal material). While analyzing the data in a descriptive analysis. The findings in this research is that the problem of arranging the authority of the execution of the decision of the National Syari'ah Arbitration Board in the sharia economic dispute in Indonesia with the overlapping of authority makes the legal confusion and does not provide justice for Muslims to obtain legal certainty as Islamic law has been in Guaranteed by Pancasila and the 1945 Constitution. For the sake of the creation of justice in society, it is necessary to reconstruct the Article 59 paragraph (3) of Law no. 48 of 2009.
\end{abstract}

Copy Right, IJAR, 2017,. All rights reserved.

\section{Introduction:-}

In article 49 (i) of Law no. 3 of 2006, the article and its contents clearly stated that the Courts of religion are on duty and authorized to examine, decide and resolve cases at the first level between people who are Muslims in sharia economics. Courts or religion are institutions in the judiciary (litigation) who have the authority to solve the sharia economic case, the settlement of the sharia economic dispute outside the court (non litigation) can be settled in the arbitration institution namely the National Sharia Arbitration Board (Basyarnas). Arbitration is the means of settlement of a civil dispute outside the general court, which is based on an arbitration agreement made in writing by the parties to the dispute in Article 1 number 1 of Law no. 30 of 1999 on Arbitration and Alternative Dispute Resolution. The dispute by way of settlement by arbitration is based on an agreement made on the basis of a written agreement of the parties, not all disputes may be settled by arbitration, but only disputes concerning the rights which are lawful (the written agreement of the parties).

In the Law no. 30 of 1999, the rule of law concerning the enactment of judgments and the execution or execution of the arbitral award, only containing the authority of the District Court, does not contain the authority of the Religious Courts, therefore there are two opinions on this matter. First, such authority is the authority of the District Court, based on Article 59, Article 61, Article 62, Article 63 and Article 64 of Law no. 30 of 1999, so that the decision of 
National Sharia Arbitration Board becomes the authority of the District Court. Second, the opinion that all relating to the sharia economic solution based on Article 49 (i) is the authority of the Religious Courts, this opinion is based on the legal principle of lex specialis derogat legi generali.

According to the principle of lex specialis derogat legi generali, that is the legislation which is of special precedence over the applicability of the general laws and regulations. The authority of the Religious Courts to carry out the Decision or Execution of Basharnas is appropriate in accordance with the legal principle of lex specialis derogat legi generali.

In view of the overlapping of authority between the State and Religious Courts, the Supreme Court issued a Circular Letter of Supreme Court (SEMA) Number 08 dated October 10, 2008, which contains the authority to implement the Shari'ah Arbitration Decision, which is the authority to execute the content of the Basyarnas decision The parties do not do voluntarily is the Religious Court. The next problem is that SEMA is no longer valid after Law no. 48 Year 2009 on Judicial Power, with the release of SEMA No. 8 of 2010 on the Confirmation of the Unlawful Circular Letter of the Supreme Court Number 08 of 2008 concerning the Execution of the Shari'ah Arbitration Decision. In Article 59 paragraph (3), stating that: "In the event that the parties do not implement the arbitral award voluntarily, District Court at the request of one of the parties to the dispute "

Uncertainty of this law would make confusion for the justice seekers so recently the Supreme Court issued PERMA RI number 14 of 2016 in article 13 paragraph (2) which reads: Implementation of the decision of syariah arbitration and the cancellation is done by the Court in the court of religious court. It is based that the issue of Muslims is solved by way of Islam which is the principle of personality as regulated in Law no. 3 Year 2006.

The value of legal certainty is a value which in principle provides legal protection for every citizen of an arbitrary power, so the law gives the state the responsibility to carry it out. The value has a close relationship with positive legal instruments and the role of the state in actualizing it in positive law. ${ }^{1}$ According to Theo Huijbers the essence of law is also a means for the creation of a just society rule (rapport du droit, inbreng van recht). ${ }^{2}$ In the aspect of Axiology, the law has values that must be obeyed and implemented by every human being in the life of the nation and the state. Laws with one another should not be contradictory so as not to be a source of doubt. Aligning legal development in the context of globalization of law. ${ }^{3}$ Pancasila is inclusive, referring to the legal system of every civilized state can still be done to free the legal sense in the field of other legal systems. ${ }^{4}$ Starting from the background of the problem as mentioned above, then there are the main problems in this research that need to be studied is revolved around the problem as follows How to Reconstruct Authority Arrangement Arrangement Decision National Syari'ah Arbitration Board In the Sharia-based Economic Dispute in Indonesia based on the value of justice?

\section{Method of Research:-}

Based on the subject matter in this research, the method used is normative juridical. Referring to Sri Sumarwani's opinion, normative research is research on legal principles, legal system, legal synchronization level, legal history and comparative law. ${ }^{5}$ The normative method according to Soetandyo Wignyosoebroto is called the doctrinal method, and some call it the dogmatic method. ${ }^{6}$ According to Sudarto, the method of normative juridical research in the broad sense is the study of the law by not only looking at its relation into the device of mere norm, but rather looking at the importance of social benefits from the formation of norms (law). ${ }^{7}$

${ }^{1}$ Lili Rasjidi, 1994, Filsafat Hukum mazhab dan refleksinya, Remaja Rosdakarya Offset, Bandung, p. 95.

2 Theo Huijbers, 1995, Filsafat Hukum, Kanisius, Yogyakarta, p. 75.

${ }^{3}$ Anis Mashdurohatun, Mengembangkan Fungsi Sosial Hak Cipta Indonesia (studi pada karya cipta buku), UNS Press, Surakarta, 2016, p. 260

${ }^{4}$ Mukhtarudin, Gunarto, Jelly Leviza, Police discretion using restorative justice approach in peaceful settlement on traffic accidents, International Journal of Law, ISSN: 2455-2194, RJIF 5.12, Volume 3; Issue 4; July 2017; P. 20

${ }^{5}$ Sri Sumarwani, 2012, Sebuah Seri Metode Penielitian Hukum, UPT UNDIP Press, Semarang. p.15.

${ }^{6}$ Bernard Arief Sidharta, Penelitian Hukum Normatif: Analisis Penelitian Filosofikal dan Dogmatikal, dalam edt Sulistyowati Irianto dan Shidarta, 2011,Metode Penelitian Hukum Konstelasi dan Refleksi, Yayasan Pustaka Obor Indonesia, Jakarta. p.143.

${ }^{7}$ Sudarto, 2010, Hukum dan Hukum Pidana, dalam Nirmala Sari, Mediasi Penal Sebagai Alternatif Penyelesaian Perkara Tindak Pidana Lingkungan Hidup di Luar Pengadilan, (Disertasi), PDIH Undip, Semarang. p.32. 
The paradigm used in this research is constructivism paradigm, that is criticizing law in overlapping authority of District Court and Religious Court in the case of execution of National Shari'ah Arbitration Board decision in sharia economic dispute in Indonesia this is for the legal certainty of the seeker of justice. In legal research there are several approaches. With this approach, researchers will get information from various aspects of the issue being attempted to find answers. Here are the approaches according to Peter Mahmud Marzuki used in this study are $:{ }^{8}$ Legal Approach, Case Approach, Historical Approach, Comparative Approach (approach), and conceptual approach (conceptual approach)

This research is descriptive, literally according to Sumadi Suryabrata descriptive research is a research that intends to make pencandraan (description) about the situations or events. ${ }^{9}$ Berbentuk perskriptif, karena penelitian ini bertujuan mendapatkan saran mengenai apa yang harus dilakukan untuk mengatasi masalah-masalah tertentu. ${ }^{10}$.

The form is perscriptive, because this study aims to get advice on what to do to overcome certain problems. The main source of data in normative legal research is bibliographic data. In the legal literature, the data source is called legal material. Legal material is anything that can be used or required for the purpose of analyzing applicable law, ${ }^{11}$ which consists of 1) Primary Legal Material, which is a binding legal substance in the form of legislation; 2) Secondary Legal Material which is the legal material which gives explanation about primary law material; 3) Tertiary Legal Material which is the legal materials that provide guidance and explanation of primary and secondary legal materials.

The legal material used in this research is obtained from the search through the literature study activities, the data analysis techniques in this study is Qualitative Analysis, this qualitative analysis is used in reviewing the material of Primary law and secondary law material by using inductive thinking logic.

The legal materials that have been collected are then analyzed using several techniques::

1. Description Technique:-

The description technique describes the situation or event. In description techniques do not seek or explain the relationship, do not test the hypothesis or make a prediction. ${ }^{12}$

2. Evaluation Technique:-

Evaluation technique is the assessment in the form of precise or inappropriate, agree or disagree, valid or invalid by the researcher to a view, statement, both in the material of primary law and secondary law material.

3. Argumentation Technique:-

Argumentation techniques can not be separated from evaluation techniques because the assessment of the analysis must be based on reasons of legal reasoning. The results of further analysis are given the argument to get conclusions on the subject matter discussed in this study.

\section{Research Result and Discussion:-}

Authority of the National Sharia Arbitration Board in the Sharia Economic Dispute in Indonesia:-

Arbitration under Law Number 30 Year 1999 is a means of solving civil disputes outside general courts based on arbitration agreements made in writing by the parties to the dispute. The provision contained in Article 3 of Law Number 30 Year 1999 states that the District Court is not authorized to adjudicate disputes of parties that have agreed in the arbitration agreement. This article affirms that a case that is being and will be delegated to arbitration, then the District Court is not authorized to judge it. Thus, there is no overlapping in the settlement of the case. It is necessary for the position of the arbitration institution to be stronger and more independent, so that if any disagreements or disputes that may arise in a particular legal relationship will be resolved through the arbitration body. ${ }^{13}$

${ }^{8}$ Peter Mahmud Marzuki, 2013, Penelitian Hukum, Kencana Prenada Media Group, Jakarta. p.133-177.

${ }^{9}$ Sumadi Suryabrata, 2010, Metodologi Penelitian, Raja Grafindo Persada, Jakarta. p.76.

${ }^{10}$ Sri Sumarwani, op.cit., p.12

${ }^{11}$ Salim HS dan Erlies Septiana Nurbani, 2013, Penerapan Teori Hukum pada Penelitian Tesis dan Disertasi, Raja Grafindo Persada, Jakarta. p.16.

${ }^{12}$ M. Hariwijaya, 2007, Metodologi Dan Teknik Penulisan Skripsi, Tesis Dan Disertasi, Azzagrafika, Yogyakarta, p. 48.

${ }^{13}$ A. Rahmad Rosyadi dan Ngatino, loc. cit, p. 72. 
In accordance with the provisions of Law Number 48 Year 2009 concerning the Basic Provisions of Judicial Authority in Article 59 paragraph (2), and Article 3 states that the parties who use the Arbitration Board as an outof-court dispute resolution body shall be implemented and followed. In the Justice Equality Act it also expressly states that the final Arbitarse decision and have permanent legal force. The juridical, open freedom for the parties to enter into an agreement by stating the arbitration clause of mutual agreement.

The core of the ability to enter into an arbitration agreement is that the agreement should be based on the "agreement" of the parties and include or regulate the arbitration agreement (consensual principal) in one of the clauses of the particular agreement. ${ }^{14}$ Article 1 number 3 of Law Number 30 Year 1999 states that: "The arbitration agreement is an agreement in the form of an arbitration clause contained in a written agreement made by the parties before a dispute arises, or an arbitration agreement made by the parties after a dispute arises".

From the formulation of Article 1 point 3, it can be concluded that the arbitration agreement arises because of an agreement in the form of :

1. An arbitration clause contained in a written agreement made by the parties before a dispute arises or

2. A separate agreement made by the parties after the occurrence of Dispute.

Accordingly, the arbitration agreement referred to as shariah arbitration referred to in Article 1 number 3 of Law Number 30 Year 1999 is very concerned with the written agreement of the parties to settle a dispute or civil dispute to arbitration or ad hoc arbitration. The agreement may also include legal options to be used for dispute resolution or disputes. ${ }^{15}$

The choice of dispute resolution outside the general court or through the arbitration of sharia, called the National Sharia Arbitration Board (Basyarnas), shall be expressly stipulated in the agreement. In general, syariah arbitration clauses or agreements are made in writing. In Indonesia pursuant to the Arbitration Act requires arbitration agreements to be made in writing by the parties. The National Syariah Arbitration Board, which also binds itself to the Law of Arbitration no. 30 of the year 1999. With the arbitration agreement (written) earlier, it means removing the right of the parties to propose dispute resolution or differences of opinion contained in the agreement to the Court. Subsequently, the Court is not authorized to adjudicate the disputes of the parties which have been bound by the arbitration agreement. Therefore, the District Court shall declare to be unenforceable and shall not interfere in a dispute settlement established in the Arbitration Act.

Accordingly, a syariah arbitration clause or agreement provides absolute authority to the Sharia Arbitration Board or ad hoc arbitration body to resolve disputes or disagreements between parties arising or may arise from certain legal relations, to which the settlement is agreed upon through the National Sharia Arbitration Board. An automatic court is not authorized to adjudicate a legal relationship dispute previously agreed upon by the parties to be resolved by means of sharia arbitration. ${ }^{16}$

As the Shariah Arbitration Board, in accordance with its name, the procedure for settlement of its case is done in accordance with the principles of sharia, it is reflected in the Procedure Rules of the National Sharia Arbitration Board (Basyarnas) in Article 22 paragraph (4) which affirms that: "Each determination and decision Beginning with the phrase Bismillâhirrahmanirrahîm, followed by the Demi of Justice by the One Godhead ".

Which is further reinforced in Article 24 Paragraph (1) of the Regulation of Procedure of the National Sharia Arbitration Board (Basyarnas) that "arbitral award shall contain: (a) the sentence of Basmallah which reads: Bismillāhirrahmanirrahîm above the head of the decision". Inclusion sentence Basmallah (Bismillahirrahmanirrahim) actually contains some ideological significance which should animate and coloring all the thinking and behavior of arbitrators in examining and deciding cases. These meanings are $:{ }^{17}$

\footnotetext{
${ }^{14}$ Suyud Margono, loc. cit, p. 116.

${ }^{15}$ Rachmadi Usman, Rachmadi Usman, 2003, Pilihan Penyelesaian Sengketa di Luar Pengadilan, Citra Aditya Bakti, Bandung, p. 119.

${ }^{16} \mathrm{Ibid}$, p. 120.

${ }^{17}$ See Mukti Arto, Penemuan Hukum Islam Oleh Hakim Demi Mewujudkan Keadilan, Bahan Pelatihan Hakim Peradilan Agama Berkelanjutan di Mega Mendung, Bogor, Dated 19 s/d 24 Oktober 2014, p. 2-3.
} 
The foundation of the ideological in examining and deciding cases:-

Sentence of Basmallah (Bismillahirrahmanirrahim) is one of the verses of Allah in the Koran which in this case is an ideological foundation in examining and deciding cases based on Islamic law, in addition to the sentence Basmallah (Bismillahirrahmanirrahim) is also a statement of devotion (worship) to God so that all the activities in resolving the case has a value of worship, as the Prophet SAW which means: "any good deeds done by the Children of Adam that does not start with Bismillahirrahmanirrahim then charity It becomes hollow (no blessing) ".

\section{Title and symbol of Islamic sharia:-}

Sentence Basmallah (Bismillahirrahmanirrahim) must animate and color the whole process of dispute resolution, including when deciding the case is in the name of Allah.

\section{Statement of accountability to Allah SWT:-}

With Basmallah sentence (Bismillahirrahmanirrahim) This means that the arbitrator realized and expressed himself that what he does is in the name of Allah and will be accountable to God. Therefore, all arbitrators must reflect the will of God the Most Just.

\section{Application of arbitrator as representative of Allah SWT:-}

The phrase Basmallah (Bismillâhirrahmanirrahîm) with all what is done during the arbiter conduct examination, consideration and decision making is an application as a representative of Allah SWT.

Specification of National Syariah Arbitration Board (Basyarnas) as the Islamic syariah arbitration body:The Basmallah sentence (Bismillăhirrahmanirrahîm) is the hallmark of the Islamic arbitration body, no other arbitration body has this characteristic other than the Islamic arbitration body. Therefore, this sentence should be written with Arabic script in accordance with the original in the Qur'an because it will feel more graceful and authoritative. This is in line with the provisions of Article 55 Paragraph (3) of Law Number 21 Year 2008 regarding Sharia Banking that "The settlement of disputes as referred to in paragraph (2) shall not be contrary to sharia principles"

The Authority of Courts of religion in the Sharia Economic Dispute In Indonesia:-

The authority to judge the environment of Religious Courts in the field of syari'ah economy can be seen in the Elucidation of Article 49 letter (i) of Law no. 3 of 2006. The explanation of the aforementioned article reads as follows: What is meant by syari'ah economy is an act or business activity carried out according to sharia principles in which, among others, covering::

1. Syari'ah Economy,

2. Sharia Microfinance Institutions,

3. Takaful Insurance,

4. Reinsurance Of Sharia,

5. Shariah Mutual Funds,

6. Syariah Bonds And Medium-Term Securities Of Sharia,

7. Shariah Securities, Sharia Financing,

8. Shariah Pawnshops,

9. Pension Funds Of Sharia Financial Institutions, And

10. Syari'ah Business.

From the explanation of the article can be seen that the range of authority to judge the environment of Religious Courts in the field of syari'ah economy has covered the whole field of sharia economy. This can be understood from the meaning of the syari'ah economic word itself which in the explanation of the article is defined as deeds or business activities carried out according to the principles of shari'ah. That is, all deeds or business activities of any kind in the economic field which is done according to the principles of shari'ah he is included in the range of authority to try the Religious Courts environment. The types mentioned in the details are only among others, which means there may be other cases in the field other than those mentioned.

As has been described in the previous chapter that the absolute authority of the Religious Courts environment in the field of syari'ah economy, in Law no. 3 Year 2006 just declared globally. Article 49 of the law states that "the Religious Courts have the duty and authority to examine, decide upon and settle cases at the first level among 
persons who are Muslim in the field of ... 1) sharia economy". Then the meaning of sharia economy itself according to the explanation of the article is "deeds or business activities carried out according to the principles of shari'ah.

From these provisions, which can be understood in relation to the environmental authority of Religious Courts in the field of syari'ah economy is included in the absolute authority of the Religious Courts environment. Whereas to the extent that the scope and extent of authority to try the environment of the Religious Courts in the field of syari'ah economy is not explicitly stipulated in the law.

As is known, the existence of syari'ah economy in Indonesia in carrying out its function of course can not be separated from the rules of law that apply nationally. The legal rules governing operational activities in Indonesia, including in this case sharia economy, in general at least consists of three areas of law, namely: the field of civil law, the field of criminal law, and the field of constitutional law. ${ }^{18}$

Then the field of law which of these three which, when violated or dispute occurs, becomes the absolute authority of the Religious Courts environment to prosecute him, and to the extent that the authority of the judiciary judges the environment of the Religious Courts in the field of law.

All cases of sharia economy in the civil sector This is the first thing that is the limit of scope and the range of authority to try the environment of Religious Courts in the field of shari'ah economy, that the authority to judge the environment of Religious Courts in the field of syari'ah economy is covering all cases of shari'a economy in the civil field.

The above statement confirms the scope of the absolute authority of the Religious Courts environment in the field of shari'a economy only covering cases or civil disputes only. This is in accordance with the provisions of Article 49 of Law no. 3 of 2006 stating that "the Religious Courts have the duty and authority to examine, decide upon and settle cases at the first level between Muslims" ... and also from the explanation of that article which states, among other things, that "dispute resolution is not only limited In the field of syari'ah economy, but also in other shari'ah economics"

From the editors of the article can be understood that the case or dispute which becomes the absolute authority of the Religious Courts environment is a matter or dispute in the field of private law only. Thus, of the three areas of law governing the operational activities of sharia economy (ie the field of civil law, the field of criminal law and the field of constitutional law), only the case or dispute in the field of private law only belongs to the scope of authority The absolute environment of the Religious Courts to prosecute him.

In the law both Article 49 of Law no. 3 of 2006 and Article 55 Paragraph (1) of Law no. 21 of 2008, expressly stated under the jurisdiction of the Courts of Religion has the authority to examine, decide and resolve cases between Muslims in the field of Islamic economics, including cases in the field of syari'ah banking. The word "finish" in both terms clearly means nothing else to carry out (execute) the judgment in relation to the cases in the field. Including in the case of executing a Shari'ah arbitration decision not executed by the parties, which was previously the authority of the District Court. With these two laws, the absolute authority of the Courts of Religion environment in the field of syari'ah economy, especially in the field of syari'ah economy is intact, no more certain parts become the authority of other judicial environment. In addition, as known Law no. 30 Year 1999 is nothing but the rules on the procedure of settling dispute settlement through arbitration. This is affirmed in Article 2 of the law which states that: This law provides for the settlement of disputes or disagreements between parties in a certain legal relationship which has entered into an arbitration agreement expressly stating that all disputes or differences of opinion arising or Which may arise from such legal relationship will be resolved by arbitration or through alternative dispute resolution. From the provisions of the article it is clear that what is stipulated in the law is nothing but the matter of the procedure of dispute settlement through arbitration. In other words, the law is nothing but a procedural law (formal law) in resolving civil disputes especially through arbitration institutions. As is known before the issuance of Law no. 30 of 1999, the procedural law applied in the settlement of disputes through arbitration is the provisions set forth in Article 377 HIR / 705. R.Bg and the provisions contained in Article 615 to Article $651 .^{19}$

\footnotetext{
${ }^{18}$ H.R. Purwoto S. Gandasubrata, 1998, Renungan Hukum, IKAHI, Cabang Makhamah Agung RI, Jakarta, p. 366.

${ }^{19}$ Ibid, p.2-3.
} 
However, after the issuance of Law no. 30 Year 1999, the whole process of dispute settlement through arbitration shall be conducted in accordance with the ways stipulated in the law. While the provisions of the arbitration contained in the HIR / R.Bg and Rv, pursuant to Article 81 of the law, shall be declared null and void. Accordingly, the provisions of the law shall be applied as procedural law in resolving civil disputes through arbitration. Including those that shall be applied by the District Court, if the arbitral award is not exercised by the parties, in addition to the provisions contained therein In Articles 195 - 208 and Article 224 HIR or Articles 206-240 and Article 258 R.Bg. Thus, from the above description it can be understood that Law no. 30 of 1999 is nothing but a part of the procedural law applicable in the general judicial environment. Because he is part of the procedural law applicable in the general judicial environment, in the case of resolving the dispute in the field of syari'ah economy, especially the field of syari'ah economy which becomes the absolute authority of the Courts of Religion environment, including in the case of carrying out the arbitration decision in that field Not implemented by the parties, in accordance with the provisions of Article 54 of Law no. 7 of 1989 as amended by Law no. 3 of 2006, the Religious Courts must apply the provisions of Law no. 30 of 1999, in addition to the provisions contained in Articles 195 - 208 and Article 224 HIR or Articles 206-240 and Article 258 r.Bg which form the basis for executing the execution of the decision.

\section{Reconstruction of Authority of Execution Decision on National Syari'ah Arbitration Board In Sharia-Based Economic Disputes in Indonesia using the Values of Justice:-}

Pancasila in its position as the source of all sources of state law because it contains ideals of law (Rechtsidee), basic values, as well as the basic philosophy for the organization of the state of Indonesia. Pancasila is the "guiding star" as well as criticism norms (rule of assessor / size / acid test) an ethical -philosophical, and becomes a margin of appreciation doctrine of all the laws that exist. ${ }^{20}$

Based on the matters which have been conveyed above in the authority of the execution of the decision of the National Sharia Arbitration Board in the sharia economic dispute in Indonesia there is overlapping authority between the District Court and the Religious Courts have the same legal basis. Although it has a legal basis but in practice its implementation is in the District Court it is based on Law no. 48 of 2009 on Judicial Power, stating that: "In the event that the parties do not implement the arbitral award voluntarily, the ruling shall be executed by the order of the head of the District Court at the request of one of the parties to the dispute" SEMA No. 8 of 2010 on the Confirmation of the Unlawful Circular Letter of Supreme Court Number 08 Year 2008 on the Execution of Sharia Arbitration Verdict.

Such a thing certainly does not provide legal certainty and not based on the value of justice for the seeker of justice, especially for Muslims in Indonesia. As a rule of law, both rulers and citizens, even the state itself must all submit to the law. All attitudes, behaviors, and deeds must be appropriate or lawful. ${ }^{21}$ Therefore based on the above mentioned in need of reconstruction of authority execution of decision of Basyarnas in dispute of sharia economy in realizing justice. Based on the theories or legal basis or legal argument which has been conveyed above the reconstruction of the authority of execution of Basyarnas decision can be done on the basis which can be explained as follows.

Whereas based on the principal issue of Basyarnas decision is the dispute of sharia economy which is the authority of Religious Court this as stated in Article 49 letter (i) Law Number 3 Year 2006 concerning Amendment of Law Number 7 Year 1989 concerning Religious Courts as already amended second With Law Number 50 Year 2009 that the Religious Courts have the authority to examine, decide, and resolve sharia economic cases.

Furthermore, the regulation on the absolute authority of the Religious Courts to handle sharia economic matters particularly in the field of sharia banking is explicitly stated in Article 55 paragraph (1) of Law Number 21 Year 2008 concerning Sharia Banking which states that "Settlement of sharia banking disputes is conducted by the courts in Environment of Religious Courts ". Although dualism still occurs, because in Article 55 paragraph (2) it states that: "In the event that the parties have agreed to settle disputes other than paragraph (1), dispute settlement shall be

\footnotetext{
${ }^{20}$ Anis Mashdurohatun, Constructing And Developing The Social Function Principle S In Utilising Copyright Products Related To The Fundamental Rights, South East Asia Journal of Contemporary Business, Economics and Law, Vol.7, Issue 4(Aug.) ISSN 2289-1560,2015. p.90

${ }^{21}$ Muhammad Khambali, Reconstruction Of Criminal Procedure Code Of Indonesia On The Subjective Reasons Of Detention Based On Dignified Justice, International Journal of Advanced Research (IJAR) ISSN: 2320-5407 Int. J. Adv. Res. 5(5),p.312
} 
conducted in accordance with the content of the Agreement", the explanation of Article 55 paragraph (2): Referred to as "dispute settlement done in accordance with the contents of the Agreement" means the following efforts :

\section{Discussion:-}

1. Banking Mediation;

2. Through The National Sharia Arbitration Board (Basyarnas) Or Other Arbitration Body; And / Or

3. Through Courts Within The General Courts.

This dualism occurs because the settlement of litigation sharia banking disputes there are two options, namely by the court within the Religious Courts or courts within the General Courts, but to end the dualism is the Constitutional Court with its decision Number 93 / PUU-X / 2012, dated August 29, 2013 Which in essence states that the Elucidation of Article 55 paragraph (2) is contradictory to the 1945 Constitution of the State of the Republic of Indonesia and has no permanent law. So that the settlement of the sharia banking dispute becomes the absolute authority of the court within the Religious Courts.

Next the authority of the National Shari'ah Arbitration Board in the sharia economic dispute in Article 3 of Law Number 30 Year 1999 states that the District Court is not authorized to adjudicate the dispute of the parties that have agreed in the arbitration agreement. This article affirms that a case that is being and will be delegated to arbitration, then the District Court is not authorized to judge it. Thus, there is no overlapping in the settlement of the case. It is necessary for the position of the arbitration institution to be stronger and more independent, so that if any disagreements or disputes that may arise in a particular legal relationship will be resolved through the arbitration body. ${ }^{22}$

As the Shariah Arbitration Board, in accordance with its name, the procedure for settlement of its case is done in accordance with the principles of sharia, it is reflected in the Procedure Rules of the National Sharia Arbitration Board (Basyarnas) in Article 22 paragraph (4) which affirms that: "Each determination and decision Beginning with the phrase Bismillâhirrahmanirrahîm, followed by In the name of justice based on the unity of the god ( demi keadilan berdasarkan ketuhanan yang maha esa)". Subsequently reaffirmed in Article 24 Paragraph (1) of the Regulation of Procedure of the National Arbitration Arbitration Board (Basyarnas) that "arbitral award shall contain: (a) the sentence of Basmallah which reads: Bismillāhirrahmanirrahîm above the head of the judgment".

Seeing the authority of Basyarnas as well as the procedure of dispute resolution of sharia economy then it should be in the execution of the decision of Basyarnas then become the authority of the Religious Courts. Then when viewed from the theory of the enactment of Islamic law in Indonesia it is very clear when there is a matter of civil law of Muslims then it must be solved by Islamic law, so that the authorities are the Religious Courts. The theory of Islamic law is: Theory of Credo or Syahadat, Receptio in Complexu Theory, Receptie Theory, Receptie Exit Theory, Receptie a Contario Theory. Based on the theory of the enforcement of Islamic law in Indonesia for Muslims in Indonesia, the state as the holder of the regulation authorizes the Religious Courts to examine and adjudicate all disputes of Muslims as their authority is regulated by law. Therefore, when there is a dispute between Muslims in terms of Islamic economics and choose to resolve through non-litigation channels in this case is the National Sharia Arbitration Board, then to realize justice as referred to the Religious Courts should be the only institution authorized to execute the decision of the National Sharia Arbitration Board If either party does not comply with the decision of the National Sharia Arbitration Board as agreed. A legal relationship is a relationship that is regulated and recognized by law and has legal consequences. ${ }^{23}$

In the case of sharia economic disputes, including the execution of Shariah arbitration decision in the settlement of sharia economic dispute, although the legal subject is not Muslim or not using sharia principles for legal entity, but because it has used transactions or business with Sharia principles, the Religious Courts are authorized Judge because according to the law he is seen by himself subject to Islamic law. Seeing that in the Indonesian state that

\footnotetext{
${ }^{22}$ A. Rahmad Rosyadi dan Ngatino, 2002, Arbitrase dalam Perspektif Islam dan Hukum Positif, Citra Aditya Bakti, Bandung, p. 72

${ }^{23}$ Anis Mashdurohatun, Gunarto, Bambang Suprabowo, Sugiyanto, In Effect of fiduciary agreement of moving object as a guarantee against obligation-violating debtor, International Journal of Humanities and Social Science Research ISSN: 2455-2070;Volume 3; Issue 7; July 2017.P.39
} 
protects the religious people and guarantee freedom in worshipping, then set the Religious Court as a forum for seekers of justice in the civil field for Muslims.

Based on the aforementioned matters so that the execution of Basyarnas's decision on the basis of the above is required, therefore Article 59 paragraph (3) of Law no. 48 of 2009 on Judicial Power, which states that: "In the event that the parties do not implement the arbitral award voluntarily, the verdict shall be executed by the order of the head of the District Court at the request of one of the parties to the dispute". In addition Article 59 paragraph (3) of Law no. 48 Year 2009 on Judicial Power, Elucidation of Article 59 paragraph (1) and SEMA No. 8 of 2010 on the Confirmation of the Unlawful Circular Letter of Supreme Court Number 08 Year 2008 regarding Execution of Sharia Arbitration Verdict, contrary to Lex Lexis Lexis Generalis Derogat Lexis Generalis principle with Article 49 letter (i) Law no. 3 of 2006 on Religious Courts and Article 55 of Law no. 21 of 2008 concerning Sharia Banking.

The regulation of Shariah okonomi dispute authority already exists in Article 49 (i) of Law no. 3 of 2006 and Article 55 of Law no. 21 of 2008 concerning Sharia Banking which in the sharia economic dispute including the execution of Shari'ah arbitration decision is the authority of Religious Court as described above, so that the legal reconstruction to be done is that Article 59 paragraph (3) of Law no. 48 Year 2009 About Judicial Power. To achieve justice in the execution of the decision of the arbitration body of sharia in the Religious Courts there must be a Legislation that binds in the law level, so as not to change quickly so as not to harm the seekers of justice, since from 1999 until now always changing from the District Court changed to the Religious Courts then to the District Court again then the last to the Religious Court as PERMA RI number 14 of 2016. The legal reconstruction required for non-overlapping and legal interpretation by the justice seekers in relation to the authority of the execution of basyarnas ruling is Article 59 paragraph (3) of Law no. In the event that the parties do not implement the arbitral award voluntarily, the ruling is executed by the order of the head of the District Court at the request of one of the parties to the dispute "to" In the event that the parties do not implement the arbitral award voluntarily, The decision shall be executed by the order of the head of the District Court at the request of one of the parties to the dispute except for the dispute over sharia economy which is decided by the National Shariah Artbitrage Board "Based on the above description of the execution of the authority of the execution of a justice-based Basyarnas ruling in order to realize a qualified execution decision and provide legal certainty. Then the reconstruction is as follows:-

\begin{tabular}{|c|c|c|}
\hline Before Reconstruction & Weaknessess & After Reconstruction \\
\hline $\begin{array}{l}\text { Article } 59 \text { paragraph (3) of Law } \\
\text { no.48 year } 2008 \text { about juduciary } \\
\text { authority, that states that "In the } \\
\text { event that the parties do not } \\
\text { implement the arbitral award } \\
\text { voluntarily, the ruling is executed } \\
\text { by the order of the head of the } \\
\text { District Court at the request of } \\
\text { one of the parties to the dispute " }\end{array}$ & $\begin{array}{l}\text { In contrary to : } \\
\text { - Article } 49 \text { (i) of Law no. } 3 \text { of } \\
2006 \text { on Religious Courts } \\
\text { - Article } 55 \text { of Law no. } 21 \text { of } \\
2008 \text { concerning Sharia } \\
\text { Banking, and also Decision of } \\
\text { the Constitutional Court on the } \\
\text { case No. } 93 \text { / PUU-X / } 2012\end{array}$ & $\begin{array}{l}\text { Article } 59 \text { paragraph (3) of Law no. } 48 \text { year } \\
2009 \text { on juduciary authority, which are } \\
\text { now states that "In the event that the parties } \\
\text { do not implement the arbitral award } \\
\text { voluntarily, the ruling shall be executed by } \\
\text { the order of the head of the District Court } \\
\text { at the request of one of the parties to the } \\
\text { dispute except the dispute over the sharia } \\
\text { economy disputed by the National Shariah } \\
\text { Arbitration Board " }\end{array}$ \\
\hline
\end{tabular}

\section{Conclusion:-}

The authority of the execution of the decision of the National Sharia Arbitration Board in the sharia economic dispute in Indonesia must be in the Court of religion as stated in Article 49 of Law no. 3 of 2006 on the Amendment of Law Number 7 Year 1989 concerning Religious Courts and Article 55 Paragraph (1) of Law no. 21 of 2008 concerning Sharia Banking. While the authority of the District Court under Article 59 paragraph (1) of Law no. 48 of 2009 on Judicial Power. The problem of regulating the authority of the execution of the decision of the National Syari'ah Arbitration Board in the sharia economic dispute in Indonesia with the overlapping of such authority makes legal confusion and does not provide justice for Muslims to obtain legal certainty as Islamic law guaranteed by Pancasila and the 1945 Constitution. That in making laws and regulations must pay attention to the norms and legal principles applicable for the creation of legal certainty and legal justice in society.

Reconstruction of law for the creation of justice in society that is article 59 paragraph (3) of Law no. In the event that the parties do not implement the arbitral award voluntarily, the ruling is executed by the order of the head of the District Court at the request of one of the parties to the dispute "to" In the event that the parties do not implement the arbitral award voluntarily, The decision shall be executed by the order of the Head of the District Court on the 
request of one of the parties to the dispute except for the dispute over the sharia economy which is broken by the National Shariah Artbitration Board "

\section{References:-}

\section{Books:-}

1. Anis Mashdurohatun, Mengembangkan Fungsi Sosial Hak Cipta Indonesia (studi pada karya cipta buku), UNS Press, Surakarta, 2016.

2. Rahmat Rosyadi dan Ngatino, 2002, Arbitrase dalam Perspektif Islam dan Hukum Positif, Citra Aditya Bakti, Bandung.

3. Bernard Arief Sidharta, Penelitian Hukum Normatif: Analisis Penelitian Filosofikal dan Dogmatikal, dalam edt Sulistyowati Irianto dan Shidarta, 2011,Metode Penelitian Hukum Konstelasi dan Refleksi, Yayasan Pustaka Obor Indonesia, Jakarta.

4. H.R. Purwoto S. Gandasubrata, 1998, Renungan Hukum, IKAHI, Cabang Makhamah Agung RI, Jakarta.

5. Lili Rasjidi, 1994, Filsafat Hukum mazhab dan refleksinya, Remaja Rosdakarya Offset, Bandung.

6. Mukti Arto, Penemuan Hukum Islam Oleh Hakim Demi Mewujudkan Keadilan, Bahan Pelatihan Hakim Peradilan Agama Berkelanjutan di Mega Mendung, Bogor, tanggal 19 s/d 24 Oktober 2014.

7. M. Hariwijaya, 2007, Metodologi Dan Teknik Penulisan Skripsi, Tesis Dan Disertasi, Azzagrafika, Yogyakarta.

8. Peter Mahmud Marzuki, 2013, Penelitian Hukum, Kencana Prenada Media Group, Jakarta.

9. Rachmadi Usman, 2003, Pilihan Penyelesaian Sengketa di Luar Pengadilan, Citra Aditya Bakti, Bandung.

10. Sri Sumarwani, 2012, Sebuah Seri Metode Penielitian Hukum, UPT UNDIP Press, Semarang.

11. Sudarto, 2010, Hukum dan Hukum Pidana, dalam Nirmala Sari, Mediasi Penal Sebagai Alternatif Penyelesaian Perkara Tindak Pidana Lingkungan Hidup di Luar Pengadilan, (Disertasi), PDIH Undip, Semarang.

12. Sumadi Suryabrata, 2010, Metodologi Penelitian, Raja Grafindo Persada, Jakarta.

13. Theo Huijbers, 1995, Filsafat Hukum, Kanisius, Yogyakarta.

14. Salim HS dan Erlies Septiana Nurbani, 2013, Penerapan Teori Hukum pada Penelitian Tesis dan Disertasi, Raja Grafindo Persada, Jakarta.

\section{Journals:-}

1. Anis Mashdurohatun,Constructing And Developing The Social Function Principle S In Utilising Copyright Products Related To The Fundamental Rights, South East Asia Journal of Contemporary Business, Economics and Law, Vol.7, Issue 4(Aug.) ISSN 2289-1560,2015.

2. Anis Mashdurohatun, Gunarto, Bambang Suprabowo, Sugiyanto, In Effect of fiduciary agreement of moving object as a guarantee against obligation-violating debtor, International Journal of Humanities and Social Science Research ISSN: 2455-2070; Volume 3; Issue 7; July 2017.

3. Muhammad Khambali, Reconstruction Of Criminal Procedure Code Of Indonesia On The Subjective Reasons Of Detention Based On Dignified Justice, International Journal of Advanced Research (IJAR) ISSN: 2320-5407 Int. J. Adv. Res. 5(5), 312

4. Mukhtarudin, Gunarto, Jelly Leviza, Police discretion using restorative justice approach in peaceful settlement on traffic accidents, International Journal of Law, ISSN: 2455-2194, RJIF 5.12, Volume 3; Issue 4; July 2017. 